\title{
IDENTITAS DAN PERAN GENDER PADA MASYARAKAT SUKU BUGIS
}

\author{
Sri Nurohim \\ Program Magister, Prodi Pendidikan Sosiologi \\ Universitas Pendidikan Indonesia \\ Email:Srinurohim@student.upi.edu
}

\begin{abstract}
Abstrak
Gender merupakan karakteristik kepribadian seseorang dan dipengaruhi oleh peran gender yang dimilikinya. Identitas dan peran gender merupakan sebuah karakteristik yang memiliki determinan lingkungan yang kuat dan berkaitan dengan dimensi maskulin versus feminine. Keberadaan suku bugis yang memiliki tradisi dan kebudayaan yang begitu unik dan berbeda dengan masyarakat indoensia pada umumnya, yaitu memiliki lima gender yang berbeda dan memiliki peran masing-masing, menimbulkan pertanyaan bagaimana fungsi identitas dan peran gender pada masyarakat bugis tersebut. Data dikumpulkan dengan strudi litelatur, menggunakan pendekatan kualitataif deskriptif analitis. Hasil dari penelitian ini menunjukan bahwa identitas dan Peran gender masih tetap melekat pada setiap individu walau dengan identitas gender yang lebih beragam. Dan dengan resiko terjadinya diskriminasi dan penolakan dari lingkungan sekitar mereka

Kata kunci: Identitas Gender, Peran Gender, Suku Bugis
\end{abstract}

\section{PENDAHULUAN}

Indonesia terdiri dari berbagai macam suku dengan kebudayaan dan kearifan lokal yang berbeda-beda dan memiliki ciri khas masingmasing. Eksistensi keberagaman bduaya dan etnis masyarakat Indonesia memegang peran penting dalam membangun bangsa Indonesia.

Masyarakat Suku Bugis merupakan salah satu suku yang mempertahankan budaya dan adat istiadatnya di Indonesia. Terdapat nilai-nilai suku Bugis yang dapat diambil nilai-nilainya. Dari begitu banyak kearifan lokal yang terdapat disuku bugis, ada satu sistem yang tidak biasa dengan sistem yang berlaku di Indonesia, yaitu sistem gender yang diterapkan di masyarakat suku Bugis Makassar. Masyarakat suku Bugis Makassar terdapat kepercayaan mengenai sistem 5 gender, atau kata lain terdapat 5 sistem gender yang berbeda. Jika di Indonesia mengakui 2 sistem gender, yaitu laki-laki dengan kemaskulinannya dan permpuan dengan feminitasnya, sedangkan Masyarakat suku Bugis mempercayai ada 5 sistem gender dengan peran yang berbeda-beda, yaitu Oroane (laki-laki), Makkunrai (perempuan), Calalai(perempuan dengan peran dan fungsi lakilaki), Calabai (laki-laki dengan peran dan fungsi perempuan), dan Bissu (perpaduan dua gender yaitu perempuan dan laki-laki dalam satu tubuh).

Hal ini sangatlah menarik untuk dikaji lebih dalam dasi sisi sosiologi, bagaimana identitas dan peran gender yang masyarakat suku Bugis percayai tersebut yang berkaitan dengan budaya dan adat istiadat setempat. Untuk dapat memahami gender terletak pada kata pembagian, yang dapat dibagi kedalam dua sifat, yaitu pemabagian sifat kodrati dan pembagian yang sifatnya berubah-ubah sehingga dapat dipertukarkan. Pembagian yang pertama merupakan pemberian Tuhan yang tidak dapat dipertukarkan antara laki-laki dan perempuan dinamakan sebagai pembagian seksual. Sedangkan pembagian peran, sifat dan watak serta tanggungjawab yang dapat dipertukarkan antara laki-laki dan perempuan itulah yang dinamakan gender (Khanafi, 2009).

Menurut (Eckert, 1998) praktek gender berbeda antara budaya yang lain, dari suatu tempat ketempat yang lain, dari kelompok yang satu dengan kelompok lainnya. Hal ini menjadi perhaian penulis untuk mengetahui bagaimana pemahaman gender di suku Bugis Makassar yang mempercayai 5 jenis gender dalam suku mereka. sementara dalam pemahaman yang ditanamankan masyarakat khususnya di Indonesia, peran gender melekat pada individu yang ditentukan secara budaya yang mencerminkan suatu perilaku dan sikap yang umum pada masyarakat sebagai maskulin dan feminine dalam suatu buadaya tertentu (Lindzey dan Aronson, 1969).

Peran gender yang terbentuk mengikuti identitas gender yang dimiliki oleh individu. 
Dalam identitas seseorang terdapat beberapa aspek yang bersama-sama membentuk identitas diri yang utuh. Identitas diri seseorang adalah inti dari pemaknaan diri seseorang terhadap identitas gender seseorang yang erat kaitannya dengan peran serta fungsi sosial dan dibentuk dalam berbagai konteks sosial (Kaplan, 1990 dalam Meissner, 2005).

Identitas gender merupakan bagian dari identitas utuh seseorang yang didalamnya terdapat keterkaitan antara gagasan seseorang tentang gendernya di masa lalu dan harapan kedepannya yang berkaitan dengan gender. Gender memang merupakan permasalahan budaya yang mengelompokan laki-laki dan perempuan untuk bersifat maskulin dan feminism dan setiap kebudayaan memiliki cara yang berbeda dalam memberikan atribusi, sifat, dan peran kepada perempuan dan laki-laki. Pada dasarnya laki-laki memang berbeda dengan perempuan jika dilihat dari jenis kelaminnya dan perbedaan tersebut bersifat biologis atau tidak dapat dirubah, akan tetapi (Atmadja, 2004) menambahkan bahwa perbedaan tersebut akan dikontruksikan secara sosialcultural sehingga melahirkan gender, yaitu tanggung jawab, pola perilaku, peran, kualitas-kualitas, dan lainnya yang bersifat maskulin dan feminin.

Lalu, bagaimana dengan identitas dan peran gender di masyarakat suku Bugis, dimana kontruksi yang dibangun dalam suku Bugis berbeda dengan kontruksi dalam masyarakat pada umumnya. Sifat maskulin belum tentu dimiliki oleh laki-laki, begitupun perempuan belum tentu memiliki sifat feminine dengan segala keharusannya. Hal ini terjadi pada suku Bugis, yang mempercayai ada 5 identitas gender dalam kebudayaannya. Di mana seseorang yang berjenis kelamin laki-laki tetapi memiliki sifat feminine dengan peran dan fungsinya seperti perempuan dan sebaliknya dengan perempuan yang memiliki sifat maskulin dengan peran dan fungsinya sebagai laki-laki. Bahkan dalam satu tubuh memilki gabungan dua identitas gender, bahkan dapat disebut netral antara maskulin dan feminine. Dari uraian diatas maka peneliti merasa perlu untuk melakukan penelitian dengan melakukan kajian dari berbagai litelatur mengenai "Identitas dan Peran Gender pada Masyarakat Suku Bugis", dimana tujuan dari penelitian ini untuk mengetahui bagaimana identitas dan peran gender pada masyarakat suku Bugis dengan 5 gender yang berbeda pada budaya dan tradisi yang mereka percayai.

\section{KAJIAN PUSTAKA}

Indonesia terdiri dari berbagai macam suku dengan kebudayaan dan kearifan lokal yang berbeda-beda dan memiliki ciri khas masing- masing. Eksistensi keberagaman bduaya dan etnis masyarakat Indonesia memegang peran penting dalam membangun bangsa Indonesia.

Masyarakat Suku Bugis merupakan salah satu suku yang mempertahankan budaya dan adat istiadatnya di Indonesia. Terdapat nilai-nilai suku Bugis yang dapat diambil nilai-nilainya. Dari begitu banyak kearifan lokal yang terdapat disuku bugis, ada satu sistem yang tidak biasa dengan sistem yang berlaku di Indonesia, yaitu sistem gender yang diterapkan di masyarakat suku Bugis Makassar. Masyarakat suku Bugis Makassar terdapat kepercayaan mengenai sistem 5 gender, atau kata lain terdapat 5 sistem gender yang berbeda. Jika di Indonesia mengakui 2 sistem gender, yaitu laki-laki dengan kemaskulinannya dan permpuan dengan feminitasnya, sedangkan Masyarakat suku Bugis mempercayai ada 5 sistem gender dengan peran yang berbeda-beda, yaitu Oroane (laki-laki), Makkunrai (perempuan), Calalai(perempuan dengan peran dan fungsi lakilaki), Calabai (laki-laki dengan peran dan fungsi perempuan), dan Bissu (perpaduan dua gender yaitu perempuan dan laki-laki dalam satu tubuh).

Hal ini sangatlah menarik untuk dikaji lebih dalam dasi sisi sosiologi, bagaimana identitas dan peran gender yang masyarakat suku Bugis percayai tersebut yang berkaitan dengan budaya dan adat istiadat setempat. Untuk dapat memahami gender terletak pada kata pembagian, yang dapat dibagi kedalam dua sifat, yaitu pemabagian sifat kodrati dan pembagian yang sifatnya berubah-ubah sehingga dapat dipertukarkan. Pembagian yang pertama merupakan pemberian Tuhan yang tidak dapat dipertukarkan antara laki-laki dan perempuan dinamakan sebagai pembagian seksual. Sedangkan pembagian peran, sifat dan watak serta tanggungjawab yang dapat dipertukarkan antara laki-laki dan perempuan itulah yang dinamakan gender (Khanafi, 2009).

Menurut (Eckert, 1998) praktek gender berbeda antara budaya yang lain, dari suatu tempat ketempat yang lain, dari kelompok yang satu dengan kelompok lainnya. Hal ini menjadi perhaian penulis untuk mengetahui bagaimana pemahaman gender di suku Bugis Makassar yang mempercayai 5 jenis gender dalam suku mereka. sementara dalam pemahaman yang ditanamankan masyarakat khususnya di Indonesia, peran gender melekat pada individu yang ditentukan secara budaya yang mencerminkan suatu perilaku dan sikap yang umum pada masyarakat sebagai maskulin dan feminine dalam suatu buadaya tertentu (Lindzey dan Aronson, 1969).

Peran gender yang terbentuk mengikuti identitas gender yang dimiliki oleh individu. Dalam identitas seseorang terdapat beberapa aspek yang bersama-sama membentuk identitas 
diri yang utuh. Identitas diri seseorang adalah inti dari pemaknaan diri seseorang terhadap identitas gender seseorang yang erat kaitannya dengan peran serta fungsi sosial dan dibentuk dalam berbagai konteks sosial (Kaplan, 1990 dalam Meissner, 2005).

Identitas gender merupakan bagian dari identitas utuh seseorang yang didalamnya terdapat keterkaitan antara gagasan seseorang tentang gendernya di masa lalu dan harapan kedepannya yang berkaitan dengan gender. Gender memang merupakan permasalahan budaya yang mengelompokan laki-laki dan perempuan untuk bersifat maskulin dan feminism dan setiap kebudayaan memiliki cara yang berbeda dalam memberikan atribusi, sifat, dan peran kepada perempuan dan laki-laki. Pada dasarnya laki-laki memang berbeda dengan perempuan jika dilihat dari jenis kelaminnya dan perbedaan tersebut bersifat biologis atau tidak dapat dirubah, akan tetapi (Atmadja, 2004) menambahkan bahwa perbedaan tersebut akan dikontruksikan secara sosialcultural sehingga melahirkan gender, yaitu tanggung jawab, pola perilaku, peran, kualitas-kualitas, dan lainnya yang bersifat maskulin dan feminin.

Lalu, bagaimana dengan identitas dan peran gender di masyarakat suku Bugis, dimana kontruksi yang dibangun dalam suku Bugis berbeda dengan kontruksi dalam masyarakat pada umumnya. Sifat maskulin belum tentu dimiliki oleh laki-laki, begitupun perempuan belum tentu memiliki sifat feminine dengan segala keharusannya. Hal ini terjadi pada suku Bugis, yang mempercayai ada 5 identitas gender dalam kebudayaannya. Di mana seseorang yang berjenis kelamin laki-laki tetapi memiliki sifat feminine dengan peran dan fungsinya seperti perempuan dan sebaliknya dengan perempuan yang memiliki sifat maskulin dengan peran dan fungsinya sebagai laki-laki. Bahkan dalam satu tubuh memilki gabungan dua identitas gender, bahkan dapat disebut netral antara maskulin dan feminine.

Dari uraian diatas maka peneliti merasa perlu untuk melakukan penelitian dengan melakukan kajian dari berbagai litelatur mengenai "Identitas dan Peran Gender pada Masyarakat Suku Bugis", dimana tujuan dari penelitian ini untuk mengetahui bagaimana identitas dan peran gender pada masyarakat suku Bugis dengan 5 gender yang berbeda pada budaya dan tradisi yang mereka percayai.

\section{PEMBAHASAN \\ Identitas dan Peran Gender pada masyarakat Bugis}

Identitas gender merupakan bagian dari identitas utuh seseorang yang didalamnya terdapat keterkaitan dengan gender. Meissner (2005) mendefinisikan gender sebagai pengalaman internal diri tentang gender dan menjadi bagian dari identitas diri seseorang. Selanjutnya identitas gender dibagi menajdi dua bagian, yaitu identitas gender inti dan identitas peran gender.

Identitas gender inti merupakan perasaan menjadi perempuan atau laki-laki yang terbentuk diusia tertentu (2 tahun) berdasarkan aspek biologis yang membedakan diri antara laki-laki dan perempuan. Sedangkan identitas peran gender adalah perasaan individu akan gendernya baik itu maskulin atau feminine dan dipengaruhi oleh faktor sosiologis, biologis, dan psikologis.

Pada masyarakat Bugis pembagian identiats gender sendiri terbagi menjadi lima, semua diakui dan mempunyai peran masing-masing. Bagi masyarakat Bugis yang disini tidak memahami dengan makna gender sendiri, mereka hanya menempatkan diri sesaui dengan pengalaman hidup yang mereka alama. Mereka menetukan diri sebagai perempuan (Makkunrai), laki-laki (Orowane), laki-laki feminin (Calabai), perempuan maskulin (Calalai), dan Bisu (gabungan antara laki-laki dan perempuan) sesuai dengan kecenderungan yang dirasakan dari kecil dan pengaruh dari lingkungan sekitar.

Gender sendiri merupakan pelabelan atas lakilaki dan perempuan. Kontruksi ini tidak lagi membedakan laki-laki dan perempuan atas perbedaan seks yang dimiliki. Dasar sosialisasi ini secara kuat telah membentuk ideologi gender, melalui kontruksi sosial yang melembaga. Misalnya, perempuan dikenal lemah lembut, cantik, emosional dan keibuan. Sementara lakilaki dianggap kuat, rasional, perkasa, dan jantan (Fakih, 2013).

Kontruksi masyarakat pada umumnya hanya ada dua ekpresi gender, yaitu maskulin dan feminine, serta sudah menjadi tuntutan 'ideal' yang melekat pada masyarakat bahwa maskulin adalah identik dengan laki-laki, dan feminine identik dengan perempuan. Akan dipandang salah atau tidak sesuai dengan tuntuna 'ideal' pada masyarakat ketika laki-laki memiliki karakteristik feminine apalagi dengan peran sosialnya pun sama seperti perempuan atau sebaliknya. Akan tetapi berbeda jika hal ini terjadi pada masyarakat tradisional dengan tradisi dan kebudayaan yang menjadi latarbelakangnya. Sama halnya dengan suku Bugis, meskipun calalai, calabai dan bissu 
memiliki populasi yang rendah tidak menjadi suatu penghalang bagi mereka yang memutuskan untuk memilih menjadi calalai, clabai atau Bissu dan masyarakat Bugis pun menerima hal tersebut karena sudah menjadi suatu tradisi kebudayaan dari para leluhur sebelum agama islam masuk ke tanah Bugis.

Pemahaman gender dalam kata pembagian dapat dibedakan pada dua pertukarkan. Pembagian yang pertama merupakan pemberian Tuhan yang tidak dapat dipertukarkan antara lakilaki dan perempuan dinamakan sebagai pembagian seksual. Sedangkan pembagian peran, sifat dan watak serta tanggungjawab yang dapat dipertukarkan antara laki-laki dan perempuan itulah yang dinamakan gender. Dari pembagian itulah kemudian muncul perbedaan gender.

Calabai yang merupakan laki-laki secara biologis, tidak dapat menukarkan dirinya menjadi seorang perempuan seutuhnya, akan tetapi peran dan identitas gender dia tetap sebagai perempuan, berpakaian dan memiliki sifat feminine adalah keputusan yang timbul dari hati karena merasa dirinya memiliki faktor $\mathrm{X}$ yang menyebabkan dia memutuskan menjadi Calabai. Begitupun dengan Calalai yang merupakan perempuan secara biologis akan tetapi memilih melakukan peran laki-laki dalam masyarakat Bugis. Hal tersebut tidak menjadi masalah bagi masyarakat Bugis yang masih tradisional dengan latarbelakang tradisi da budaya, akan tetapi hal ini menjadi suatu pertanyaan dan masalah ketika masuk kedalam pandangan masyarakat umum. Ditambah ketika hal itu dihubungkan dengan orientasi seksual mereka, ketika calabai yang pada dasarnya laki-laki tapi memiliki peran sebagai perempuan dan menikah dengan seorang calalai yang pada dasarnya adalah perempuan tapi mengambil peran sebagai laki-laki. Disini akan terjadi disfungsi peran gender dalam rumah tangga mereka.

Menurut Basow (1992) dalam Wathani (2009), peran gender merupakan istilah psikologi dan kultural, diartikan sebagai perasaan subjektif seseorang mengenai ke-pria-an (maleness) atau kewanitaan (femaleness).

Secara umum peran gender adalah sekumpulan pola perilaku yang menjadi harapan sosial untuk ditampilkan secara berbeda oleh lakilaki dan perempuan sesuai jenis kelamin. (Weinreich, 2003) menjelaskan bahwa identitas gender seseorang merupakan hasil bentukan dari pengalaman-pengalaman di masa lalu dan secara berkesinambungan dengan harapan seseorang sesuai dengan identitas gendernya.

Peran gender pada Calabai dan Calalai menjadi terbalik antara perempuan dan laki-laki hal ini menjadi sebuah permasalahan tersendiri karena patriarki berperan menentukan 'fungsi' peran gender yang jalankan oleh perorangan dalam struktur masyarakat. Laki-laki yang terlahir secara biologis sebagai laki-laki maupun yang dibesarklan sebagai laki-laki (Calalai) atau perempuan yang dilahirkan secara bilogis sebagai perempuan, maupun dibesarkan sebagai perempuan (calabai) masih beranggapan bahwa laki-laki dan perempuan memiliki tugas masingmasing yang berbeda. Maka ketika Calabai menikah dengan Calalai maka peran gender mereka akan bertukar.Calabai yang secara biologisnya adalah laki-laki maka akan bekerja di ranah domestik, sebaliknya Calalai yang secara bilogis adalah perempuan memiliki kewajiban bekerja sebagai kepala rumah tangga dan bekerja mencari nafkah.

Peran gender pada Bissu (gabungan anatara laki-laki dan perempuan) akan berbeda dengan identitas gender yang lainnya. Selain dianggap sebagai orang suci dan memiliki peran sosial yang penting pada masyarakat Bugis. Bissu pun tidak boleh menonjolkan salah satu identitas gendernya, baik itu sifat perempuannya atau laki-laki, jadi disini seorang Bissu harus bersifat netral. Lalu bagaimana dengan peran gender seorang Bissu, hal ini menjadi tidak sesuai dengan 'idealnya' masyarakat umum. Tapi sekali lagi karena Bissu terdapat pada masyarakat tradisional, tepatnya masyarakat Bugis maka hal ini tidak dapat disalahkan juga, bahka untuk menjadi seorang Bissu bukanlah hal yang mudah, selain tidak boleh condong terhadap jenis kelamin tertentu, seorang Bissu pun harus memiliki keahliankeahlian tertentu.

Kembali kepada masyarakat Indonesia secara umum yang sudah merekontruksi bahwa peran gender pada individu yaitu laki-laki maskulin dan perempuan feminine menjadi dasar penilaian bahwa hal diluar itu dianggap tidak 'ideal' dengan harapan masyarakat. Begitupun terjadi pada masyarakat Bugis sendiri. meskipun dalam struktur masyarakat Bugis keberadaan lima gender tersebut sudah ada selama ribuan tahun, bukan berarti mereka bebas dari diskriminasi dan kemudian dengan otomatis diterima oleh masyarakat. Terlebih sejak masuknya Islam yang ajarannya bertentangan dengan budaya tradisional suku Bugis.

\section{KESIMPULAN}

Berdasarkan rumusan masalah mengenai bagaimana identitas dan peran gender pada masyarakat Bugis dapat disimpulkan bahwa identitas gender pada suku Bugis menjadi salah satu ke khasan tersendiri bagi suku Bugis,pembentukan identitas gender tersebut 
sudah ada sejak mereka menyadari adanya faktor tertentu yang menyondogkan mereka untuk memilih salah satu dari kelima identitas gender yang mereka pervayai. Dengan keberagaman identitas gender yang diberlakukan bukan berarti peran gender menjadi berubah. Peran gender masih tetap melekat pada setiap individu walau dengan identitas gender yang lebih beragam. Dan dengan resiko terjadinya diskriminasi dan penolakan dari lingkungan sekitar mereka.

\section{REFERENSI}

Abdullah, H. (1985). Manusia Bugis Makassar: Suatu tinjauan historis terhadap pola tingkah laku dan pandangan hidup manusia Bugis Makassar. Jakarta: Inti Idayu Press.

Abidin, Zainal. (2007). Analisis eksistensial. Jakarta: PT Rajagrafindo Persada.

Brawn, D. M. (1993). Immanent domains: Ways of living in Bone, Indonesia. Ph.D Thesis.

Anthropology Department, Michigan: the University of Michigan.

Eckert, Penelope. 1998. Gender and Sociolingustic Variation. In Jennifer Coates. Language and Gender. Massachusets: Blackwell Publisher, Ltd, pp 64-75

Fakih, Mansour. (2013). Analisis Gneder dan Transformasi

Sosial. Yogyakarta:Pustaka Pelajar.

Hyde, Janet Shibley. 2007. Half the Human Experience: The Psychology of Women. USA: Houghton Mifflin Company

Idrus, N. I. (2003). To take each other: Bugis practice of gender, sexuality, and marriage. Ph.D Thesis. Canberra: Research School of Pacific and Asian Studies. Australian National University.

Khanafi, Imam. Makalah disampaikan pada acara workshop "Integrasi Adil Gender Dalam Proses Pembelajaran di Madrasah", (Pekalongan, tp: 2009).

Lindzey and Aronson. 1969. The Handbook of Social Psychology. Vol. I. New York: John Wiley and Sons.

Mahmud, M. (2017). The Roles of Social Status, Age, Gender, Familiarity, and Situation in Being Polite for Bugis Society, 9(5), 58-72. http://doi.org/10.5539/ass.v9n5p58

Meissner, W. W. (2005). Gender Identity and the Self: Gender Formation in General and in Masculinity. Psychoanalitic Review, 92, 1.

Millar, S. . (1983). on interpreting gender in Bugis society, 477-493.

Millar, S. (1989). Bugis Weddings: Rituals of Social Location in Modern Indonesia. Berkeley: Center for South and Southeast Asia Studies, University of California.
Mustadjar, M. (2013). Gender in the Cultural Frame and Religious Value ( Case Study of Bugis Couple Family ), 4(2), 431-437. http://doi.org/10.5296/jsr.v4i2.4718

Weinreich, P \& Saunderson, W. 2003. Analyzing Identity: Cross-cultural Societal, and Clinical Context. USA: Routledge 